\title{
CHALLENGING ENVIRONMENT IN CHILDREN'S LITERATURE CLASSIC
}

\author{
Nahidh Falih Sulaiman \\ Asst. Prof. Dr., Department of English, Faculty of Arts-Zwara, Alzawia University, Libya, \\ nahidhum@gmail.com
}

\begin{abstract}
Mostly, families used to look for certain books to share their enjoyment with their children for purposes of guidance, inspiration, creation, development, and introducing an enchanting world. Crossing boundaries is one of the most important goals that help children to empower their mentality and to enrich their emotional reactions of love, nobility, and sympathy. Classic children's stories help to create an imaginative world which is most memorable and notable. Such stories fill children's life with senses of challenging and possibilities to live the impossibilities as well as they shape children and reader's life style with values and traditions through characters and ends. In comparison with the recent children's stories and arts, those classics are distinguished by many details that are challenged by scenes of death, shedding blood, depression, unfamiliar weapons, and violence. Themes of separation from and reunion with parents, rebirth after sleeping-like death, justice after struggle, oppression of stepmother, or the lifelong spell of a witch were all subjugated to be changed into intensive aggressiveness and harshness of realities. Hence, the researchers of this paper try to shed the light on the influence of classic bedtime stories that tackled the sudden soul mate presence and the effect of love in transforming imagination into reality, in a semi comparative analysis with an example from modern children's story. Moreover, these stories suggest that modernity brings abandonment and alienation to kids and leads them to no home to belong. Children who used to be told these stories or watched them are not happy as they are frightened to be abused or attacked. They are fearful of what is coming next, troubled of horrible dreams, and trust no one. Therefore, there will be a possibility to present an aggressive generation.

The challenge under the scope of children's literature encourages the researchers returning to some classic stories when a knight's kiss resurrects the dead feelings of a princess giving her a rebirth. While modernity in children's literature moves to complex phases of development in that teacher, academic curriculums, movie makers, story tellers, and children celebrate that confused part. Hence, the paper investigates valuable traditions of worth researching to remind in the first part through some traditional fairy tales such as Sleeping Beauty and the Seven Dwarfs. While the second part deals with the suspense and tension in The Tale of Peter Rabbit as a British children's book. The paper ends up with a brief conclusion that shows the comparative imagination and fantasy in classic and modern children's literature.
\end{abstract}

Keywords: Children's Literature, fairytales, traditions, feminist rights, oppression and justice 


\section{THE IMPORTANCE OF CHILDREN'S LITERATURE}

The messages within children's literature help in establishing fertile lands for children's imagination and feelings. Fundamentally, stories are not limited to bedtimes, but rather of how to concur negativities of fear and psychological complications. Going deeply through and developing a critical insight are among goals that help children to discover the undiscovered paths of life and to evaluate daily experiences of their own.

Searching for meaning in children's stories is an actual opportunity to resurrect the past and to enhance the heritage. Such an enhancement whether in traditional or new, real or imaginative story events add wonderful and magical experiences to live these events within the phase of past and to be a part of their success and popularity. Children are given chances or maybe real parts to convey messages of these stories to the coming generations with new interpretations and insight. Their foundations and abstracts of their private world which are derived from stories are fixed in child's mind and connected with some eventual situations through coincidental matches that synchronize time and place.

Although meanings could be understandable by children and adults, yet their interpretations might be different by both. Beside, old and new children and adults generations find a puzzling situation in functioning these meanings and messages due to their own time. Eventually, children counter a dilemma in linking the pure innocence of their own with the intensive development and situations of today. Feelings of hatred, love, romance, joy, anger, fear, sadness, or nobility are re-acted differently by children who want to discover another horizon and limits. Yet, these emotional powers feed minds and hearts of worthwhile sensitivities. Such sensitivity prepares children to be within the core of life and to have a part in the essence of it. On the other hand, literature provides terms and vocabularies that are not common or familiar by children, yet they are easily understood through colorful pictures and drawings. Here, children learn, imagine, listen, watch, and comprehend. This set of mental activities will reinforce the process of acquiring language in standard or local structures. Children's literature allows them to gather words for making up useful sentences. Moreover, learning new words and phrases will help to develop brain sensitivity and awareness of what is coming next with all expectations. The repeated words in children's books attract a child to utter these words frequently and inspire him/her to use them in daily life situations. Beside, the positive link between the printed word and its illustration will increase the child's ability to remember its meaning and messages. In children's literature, children learn to get the benefit of combining enjoyment and knowledge. Other meanings of sharing and promoting are equally tackled by children's personal development and self-expression.

\section{PART ONE: CLASSICS OF CHILDREN'S LITERATURE}

Many of studies that involved in children's literature focus on this genre as one that is written to entertain children and to create a baby-world environment. While there are many unique characteristics in children's books that deserve to be studied as a scientific field under the shining spot light. As a key word, children's studies start to educate and bring knowledge to children and adults as well through moral lessons and values. Culturally, these morals became a main part of nation heritage and the barrier of their cultural treasures. Kimberly Reynolds (2004) asserts in the introduction of Modern Children's Literature: An Introduction that this literature goes hand in hand of main importance with other studies of adults:

Those who have not ventured into the field of children's literature may assume that it is in some ways easier than the study of 'adults' literature. Nothing could be further from the truth. A key reason for this can be seen in the fact that no academic teacher or researcher would be described as an expert in 'adult literature'

In a consideration to stories of children, most assume that this genre has written and retold for children during bedtime or gathering in a warmly place with grandparents to hear stories of the past about princesses or wicked queens, or may sleep while retelling events about the beauty of nature and kingdom. In most times, these books of classics are liked by family members for their pure merits for helping and teaching. They are evaluated as rewarding books bought for good behaving child. In modern specific considerations, these classics had often been of traditional and out-style fashion and boring friends to young readers. To modernists, these classics are no more than refreshing innocence and naivety. Moreover, modern style suggests that "children themselves, of course, do not like the word and today it is fading in importance" (Bechtel, 1969). What is fixed in minds of contemporary scholars and publishers that these classics satisfy the interest of pictures, cover title, or the colors without a real examination of mental benefits.

The children of twentieth century were inspired of what attract adults. Regularly, they find a great deal of attraction and inner interaction in stories of realistic category. Through successful transferring, the events of modern tales change children's indolence into energetic activities with coincidental romance. Scenes of killing are no longer fearful. They are successfully connected with themes of victory and bravery. For 
instance, Buffy the Vampire Slayer, TV series 1997-2003, ranked as children and adult's show that gathers the angelic and vampiric reactions. It emerges as one of modern tendency of nowadays. The intrusion of fantasy and the temptation of risks and vampiric romance add emotional development that increasingly pushed to popularity and necessary demands.

In classics, the considerations of merits, advantages, and quality are the goals that lead to resurrection and recreating treasures of romance, courage, nobility, worthiness, imagination, and spirituality. In a positive comparison, celebrating classics is another reason for causing anxiety to read modern children's literature. The hustle of the modernity and the innocence of the classic are deepened in children's minds in the process of challenging and concluding. To Ezra Pound, classic is distinguished by "unique freshness" 'Gamble, 2013). It established the body of fiction through retelling folklore and fairytales of traditions, to be the indicator of well-selected pieces of general classic literature. Classics are always remembered, alive, moving from one generation to another, never be faded. Although these classics were written and told by dead people, yet their popularity survives in minds and cultural identity. To the supporters of the classics, children's responses to these classics are active and spontaneously positive. To them, classics open other hidden worlds of past and encourage them to enter these worlds. In much similarity with the scene of entering a new colorful world by knowledge-seeker Alice in Alice's Adventures in Wonderland, children importantly eager to discover the unfamiliarity through suspense and exploration. Alice's Adventures closely related to a phase of moral code in that children could find simplicity and creativity within the mass of changing time and places. The same happens with Gulliver's Travels when Swift realizes that the collapse of morals could be defeated by obtaining faith and strong belief in freedom and justice.

As a part of children's literature, fairy tales are considered a main branch of children's classics that represent rediscovering the past. Through their radical messages, fairy tales are judged as dangerous to children's innocence because of some themes such as evil, wickedness, jealousy, hatred, and oppression. Moreover, they are considered as another controversial source of gender discrimination for women appear in most tales as the feminine sound of evil. They are wicked and devilish. In most Once Upon a Time, the tales start with the simplicity and beauty of life rapidly distorted by the presence of a witch or an evil spirit. Stepmother, stepsisters or a spell-spreading feminine had chosen to frighten children's minds with hatred and evil. In Cinderella, the stepmother is hated with the guilt of badly treatment to Cinderella. She stands as that ugly woman of merciless heart and economic consideration. Hence, this pattern of the familial and social exploitation by Cinderella's stepmother had been contrasted by the intervention of morals of mercy and justice that balanced the contrast of the episodes. Through the supernatural being, godmother, this intervene plays an important sociological role that closest to that of the biological mother (Pace, 1982). Dramatically, the fairy godmother supports the moral behavior of must-to-be society. She represents what justice could happen to oppressed people and how this justice could affect positively on other generations coming after. This opposition between the images of the stepmother and the godmother shows another social contrast on the part of social evaluation for a mother has no economic advantages for caring children.

In Once Upon A Tme, fairies are able to transform evil to goodness as they can see the virtues of poor more clearly and challenge the devilish-like characters in an interesting ambivalence. Their tasks as holding-role of transformation motifs the reader's belief in the fact that oppression is endless, never long lasting power and justice has a certain time to come. This sort of fact is diagramed throughout the final episodes of Cinderella in a final outcome:

$$
\begin{aligned}
& \text { Cinderella (oppressed) -------------------Victorious } \downarrow \\
& \text { Stepmother (oppressive) ----------------defeated } \downarrow
\end{aligned}
$$

(Conceit, vanity, ugliness, Evil, dirtiness)

\section{Diagram (1)}

In a study case of familial relationships, Cinderella presents a pattering analysis of these threatened relationships. Children are led to know and learn through the early loss (death or departure) of a father that this loss might expose a family to another certain loss. Furthermore, the evil behavior of the stepsisters might end up a situation with a frustration among themselves. In Cinderella, this analysis is also diagramed as follows: 


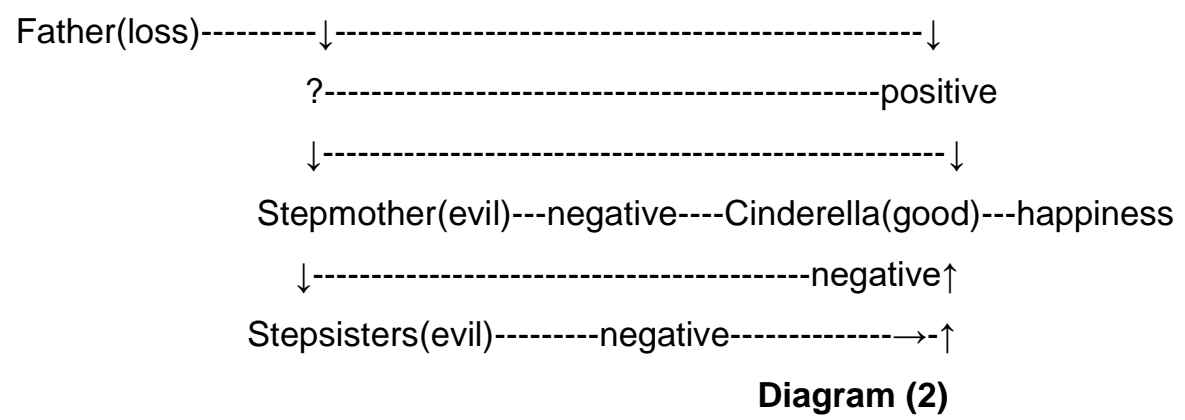

Readers of the classics believe that oppression and justice are two forces equally are faced and lived. These two contrasted majorities inspire children and adults readers to develop their general look of how to deal psychologically and sociologically with their sequences. On the other hand, the modern analysis of this classic story appreciates Cinderella from different points of view. To feminist and womanist activists, Cinderella's silence and complete submission to oppression make her a passive model of feminist rights. She is subordinate and surrenders to fate and extra forces. Thus, Cinderella was evaluated as a powerless story told to powerless readers and audiences. Silence of Cinderella may kill that determination of modern society in a time when there is a real need to create powerful generations.

The expressions of submission, silence, and subjugation of women are confronted by feminist's focus that directed these expressions to challenging and transforming. This silent-ever creature should be transformed from marginalization to centralization with a full engaging in the diversities and new strategies of the modern world. Hence, drawing attention to women-centered folktales clarifies that women are centered in their cultures and identified as a story type of societies as storytellers or heroines (Haase, 2004).

From modern point of view, children of classic stories should respond to fairytales and folklore in modernizing responses believing that victimized and silent women should be questioned and argued. Heroines have to move to more positive images of self-assertion, creativity, identification, and selfexpression. They should gain the unexpected power to go on. Two contrasted examples may illustrate this explanation. In the classic story of Snow White and the Seven Dwarfs, the submissive silent heroine surrendered to her deadly fate by eating the bloody apple and by waiting a living-kiss of the prince. To feminists, this faint-power princess waits an outer force but not her own to rescue her and to make that fatal change in her life. However, feminism confirmation on moving on and developing the interest of these fairytales are not a matter of reducing their importance, yet the matter is how to reaffirm the identity of a woman in comparison with the masculine authority. In a very recent children's literature, Maleficent, a WaltDisney 2014 film production, explores a villain-merciful Maleficent, the fairy who curses Princess Aurora in a developed vision of the animated classic story of Sleeping Beauty. In an intersecting with the classic, Maleficent is an avenger outcast fairy who loves and likes to live that normal life of human. She adds more enchantment to the story. She is love-suffering female, heart-wounded woman and betrayed by a human, yet she is powerful. To modern general tendency, Maleficent represents a positive image of women. As a strong woman, everyone fades in her presence. All are silent in fear, yet are all inspired by her beauty and femininity. Maleficent's silence and submission are transformed into sudden self-awakening that turned out her hurt with all her emotional flooding into horrible acts and revenge when she discovered the loss of her power (wings). In an analytical performance, losing these wings is the loss of one's identity, self-esteem, and creativity. Hence, children of modern stories have been told through this modern revised story that innocence might be transferred into severity when it is abused and exploited. In addition, morals and values such as sacrifice and goodness are timeless. In Maleficent, Angelina Jolie presents cruelty of woman that mixed with messages of immortal values of love and romance. On the other hand, villains are created out of pain. They are unworthy, derived from difficulties of friendless existence. Those evil-holding characters are children's examples of the triumph of rightness that shaped sometimes our living with a temporary evil victory. Thus, there are more lessons in each of these classic stories painting that everything has two sides, a balance of two scales. They swing up and down or a light that once turns on and second turns off.

\section{PART TWO: MODERNITY IN CHILDREN'S LITERATURE}

Children's literature witnessed a prolific development to be tackled and learned as an academic genre. Among the most developed factors is the assumption that modern children's literature is written to all ages and for any audience. Modernity in children's books has migrated from works for early children's stages to listeners and readers of more experienced and mature. In challenging preserving, childhood is seen as a valuable base that should be treated neither as mere innocent knowing of no concrete experiences nor as adults passing to personhood and typifying for hard status. 
Fictionally, childhood scenes are presented excessive in imagination that moves towards depressed reality more than addressing the humanity in child. Though searching for the real sights and educational recognition, truth in modern children literature tend to forget important notions of humanist childhood, romantic child, non-experienced beginners, and the possibility of reverse results. Hence, children's literature is considered by many scholars as a theoretical responsibility that has much to do with nostalgia and idealization (Rudd, 2013). A child in modern literature should be presented as innocent, inexperienced, and lack of life experiments. This child has to stand a way from the wheel of life. Their literature should be presented apart from the language misunderstanding, political and social problems of racial discrimination, human rights, and identity.

Language in children's literature is also under the scope of importance that centered in the mind of children's book writers. The language is used in this domain refers to the words which are used by both, the writer and the characters. To guarantee the fictional influence, writers use the character's language of the actual speech believing that magic of fairytales should be balanced with the reality of language. Beside, the simplicity of characters encourages writers to use their natural communication and sometimes locality in speech. This simplicity helps to easily understand the events of the stories and their lessons, messages, and thought. Modern children's literature celebrates the focus on how to develop the mentality of children through language that based on actions and unfamiliarity. Through using sceneries of vehicles, weapons, or wars, vocabularies and expressions are selected to fit these

Through general outlook, children literature began to maintain the qualifications of literature that develops to be in the need of not only children but adults and sociological thinkers as well. Children of the twentieth and twenty-first centuries no longer believe in the mere imagination and the fantasy of romance. Their intentions are moved from religious and moral instructions to literature of action. Willingly or unwillingly, children's thinking and styling are promoted and maturated by illustrated ideas of aggressiveness. In a rapid development, children's books of entertainment were quickly replaced by books of scientific purpose of strange beings. Contemporary child became aware of reading, listening, and watching stories of visual imagination that provides mental stimulation and bodily activities. Such a kind of innovation in children's literature drew a line of flourishment and maturation that helps in turn to foster children's literary criticism to be emerged in 1924 in The Horn Book Magazine in Boston.

Most modern children's literature stories are driven from the classic fairy tales or folklore. Through developed tools such as using graphic novels or 3HD children's movies, these tales shape themselves with the children's needs of today. For instance, Hansel and Gretel: Witch Hunters is the American-German dark fantasy of an action-horror episode of 2013. It is a modernized continuation of the German fairytale Hansel and Gretel in which the story illustrations had changed to horrors of cutting heads and shedding blood. In the newest one, Hansel and Gretel is written to due to the motion threats of the contemporary way of thinking. Scenes of slaying, cut heading and making love are available with the reunion of the brother and sister. Spell and curse of the classic story version are linked with the modern threats of cannibalistic witches and arsenal of weapons. Due to the modern treatment, movies that based on the original stories would have a scientific intention to insert a modern spin to all past actions. Characters and weaponry refresh the classical darkness of the old Hansel and Gretel in Hollywood production style. In this episodic example, the idea of the oppressed brother and sister is grown up to be the hunters of witches. It is an old style of feeling of hatred towards witches' spell but in a technological treatment in which actions of shotguns are used as a motivation to save people, end curses, and fight evil. So, readers of modernity are hugely influenced by such a technological fantasy world of giving them another interesting feeling of playing a combat game that they have to finish it victorious. Moreover, in modern style, the character of witches seems more attractive and stylish without that old shape of pointed nose and long nails. Although witches are nasty and fearful, yet they are modernized to be awesome of physical beauty and attractiveness. They are influenced by the twilight transforming to other being of less faded danger that has a clear link with the faded witches' curse by a prince's kiss or good actions of a godmother fairy.

ritics work on another interpretation of children's literature that focus on modernity to formulate this sort of literature as 'true' books that are associated with freedom and creativity. Although Grimm, Anderson, and Perrault dominated children's books as sources of child's imagination and cultural celebration, yet modernity in children's books attributes any development in children's mentality and creativity to the modern vision of children's stories and retellings. Here, childhood is associated with adulthood that refuses any separation of characteristics between the two age stages which indicates that children's books are ranked more important in learning and analyzing before starting with adult's literature.

The fact that classic children's books are based on reward and punishment and results that all based on romantic perception, is developed to re-focus on cause and effect principle that sometimes includes sexual 
and racial balance. Some of children's book writers and critics assert that involving modernity in children's literature means damaging childhood. C.S. Lewis (1966) in his "On Three Ways of Writing For Children" points out that the pleasure of old values in classics are irreplaceable. They are affected negatively by modern development. He asserts:

The modern view seems to me to involve a false conception of growth. They accuse us of arrested development because we have not lost a taste we had in childhood. But surely arrested development consists not in refusing to lose old things but in failing to add new things?

According to modern thoughts, involving conceptions of growth in children's books does not corrupt the natural mental and emotional development of children. On the contrary, the exploration of the new world in children's books allow to discuss firstly the important familial relationships that are affected badly by time and works, and secondly to examine the social world and the child's participation vitally in all of its fields. Through modern focus, children develop their sense of personal self. The concentration on psychological representation is depicted through the clashes of self desires and the conflict of inner self. Through psychological point of view, modern children's books search deeply in the different status of mind. This kind of psychoanalytical exploration helps in symbolizing the outer world through imaginative or real characters and in realizing the unconscious mental life of a person (Rustin, 1987). Socially, these books offer a real opportunity to a child to minimize the whole real world in his book or narratives. Through this representation, mental and emotional considerations are considered goals that are emerged in modern children's literature.

The classification of children's literature as classic and modern established to be seen as a suitable tool for each time and age. Themes of individuality, identity and life complexities started to be visible in the literary genre for children. Mostly, these themes are combined with fantasy of horror. For instance, Beatrix Potter's The Tale of Peter Rabbit (1938) shows a successful involvement of words and images in fantasy and reality. Peter Rabbit represents the senses of tension and fear of human being of the modern age in the animal character of a rabbit when it is threatened by a murderous human Mr. McGregor who represents the source of fear and threat of life. As a part of reality, Peter is a rabbit, but it cries and dresses as human. In a certain time when it became wild, Peter represents themes of self-indulgence and the transgression of human that are away of search in classics.

Zombies in children's literature are necessary to be considered a developed domain in children's stories. Such tales are associated in writing with some purposes. Firstly, zombie is linked with the human survival and the desire to live continuously. It represents human's instinct to refuse fatal ends like death. Secondly, zombie appears as the result of losing self and volition (Boon, 2007). To modern critics, zombie represents the real threat to human's lives and stability. It disturbs the natural ideology of life. Zombies are a real threat to children's innocence and adult's thinking as well. Thirdly, zombie is that dark part of the soul. it is the negative appreciation of living peacefully. It is the remaining of the spirit in a moment when the body is aimlessly living. Zombie abstract character represents the left-behind part distorted by modernity. It is that corpse which is misled by selfishness, aggressiveness, and terrorism.

As the darkest side of human's aggressiveness, zombie is encountered by humanity with refusal and outcast. To children, zombie is not only a physical threat, but it is fear from the future features and the ugly face of what is coming after. Intentionally, zombie is shown as the awareness of losing morals and values and a lesson that shows the ugliness of heading all to the loss. On the other hand, zombie in children's literature is a motif to discover other meanings such as cannibalism which is real and existed.

Although zombie bears a fearful vision to children, yet that living corpse helps the child's imagination to search what is next after death, what life could offer to human that death could not do? Thus, to understand zombie writings, children need to know the real meaning of soul loss. William Buehler Seabrook, an American explorer and journalist, defines zombie as: the zombie...is a soulless human corpse, still dead, but taken from the grave and endowed by sorcery with a mechanical semblance of life (Boon, 2007). Elizabeth Levy's Gorgonzola Zombies in the Park (1993), shows that the imaginative character of zombie turned to be real by some strange zombie things start to happen. In this children's story, a child is helped to learn that some strange events in life may become familiar and a child should be used to live with strangeness and unfamiliarity. Moreover, such stories may empower children to increase their eagerness for unexpected and unusual cases.

Images of zombies or vampires are monsters fantasy that is used by children's writers to consider what is the real meaning of humanity and the result of losing it. These images show the rapid shift from simplicity and romance to intensive mood of aggressiveness. On the other hand, these stories meant to create heroes of special power and will to fight evil and to transfer that darkness into splendid light. Such stories encourage children to use their imagination to find superhuman powerful heroes to save their innocence from distortion. 
They are questioning the purpose of telling and writing stories that are different than classics when the latter are qualified by romance in defeating evil.

\section{CONCLUSION}

Children's literature is a powerful norm of acquiring knowledge and effective social behavior. It is the reflection of cultural identity and the fictional category to enhance self-expression and self-development. It is that domain of literature which adds meaning, enjoyment, and understanding to people living as well as it participants in accumulating set of experiences whether real or fictional. Children's literature proves its value of more than books of bedtime pleasure that end with the turning off the light. It has a message of clear or hidden meanings and ideas that send power, positive emotion, energy, and insights.

\section{REFERENCE LIST}

Bechtel, Louise S. (1969). "Thinking About Children Classics". In The Packet, Vol. 5-13. D.C. Heath and Company: The University of California. 167-8.

Boon, Kevin A. (2007). "Ontological Anxiety Made Flesh: The Zombie in Literature". In Monsters and the Monstrous Myths and Metaphors of Enduring Evil. By Niall Scott. New York. 33-45, 37.

Butler, C. and Kimberley R. (eds.)( 2004). Modern Children's Literature: An Introduction. $2^{\text {nd }}$ edition. New York: Martin Press LLC.

Gamble, Nikki, Exploring Children's Literature: Reading with Pleasure and Purpose.SAGE, 2013

Haase, Donald (ed.)(2004). Fairy Tales and Feminism: New Approaches. Detroit: Wayne State University Press.

Pace, David P. (1982). "Beyond Morphology: Levi-Strauss and the Analysis of Folktales". In Cinderella, a Casebook. By Alan Dundes. Wisconsin: The University of Wisconsin Press.

Lewis, C. S. (1966). Of Other Worlds; Essays and Stories. Florida: Permissions Department, Harcourt, Inc.

Rudd, D. (2013). Reading the Child in Children's Literature: An Heretical Approach. Palgrave Macmillan.

Rustin, Margaret \& Michael Rustin (1987). Narratives of Love and Loss: Studies in Modern Children's Fiction. Revised edition. London: H. Karnac (Book) Ltd. 